\title{
The Effect of Body Checking Policy Changes on Concussion Incidence in Canadian Male Youth Ice Hockey Players: A Critically Appraised Topic
}

\author{
Brittany M. Ingram, Melissa C. Kay, Christina B. Vander Vegt, and Johna K. Register-Mihalik
}

\begin{abstract}
Clinical Scenario: Current studies have identified body checking as the most common cause of sports-related concussion in ice hockey across all divisions and levels. As a result, many hockey organizations, particularly in youth sports, have implemented rules making body checking to the head, face, and/or neck illegal. Such a rule, in Canada, makes age 13 the first age in which individuals can engage in body checking. Despite these changes, effectiveness of their implementation on the incidence of concussion in Canadian male youth ice hockey players remains unclear. Clinical Question: What is the effect of body checking policy changes on concussion incidence in male youth ice hockey players? Summary of Key Findings: Of the 3 included studies, 2 studies reported a decrease in the incidence of concussion once a body checking policy change was implemented. The third study showed an increase; however, it is important to note that this may be due, in part, to increased awareness leading to better reporting of injuries. Clinical Bottom Line: Current evidence supports a relationship between body checking policy implementation and decreased concussion incidence; however, more research is needed to understand the long-term implications of policy change and the effects in other leagues. In addition, further data are needed to differentiate between increased concussion incidence resulting from concussion education efforts that may improve disclosure and increased concussion incidence as a direct result of policy changes. Strength of Recommendation: Grade B evidence exists that policy changes regarding body checking decrease concussion incidence in male youth ice hockey players.
\end{abstract}

Keywords: education, disclosure, rates, rule changes

\section{Clinical Scenario}

Youth ice hockey participation has exponentially increased over the last decade with over 600,000 young athletes currently participating each year. ${ }^{1}$ Ice hockey, a collision sport, characterized by high speed, strength, and endurance, predisposes players to a high risk of injuries, including sports-related concussions. Body checking in ice hockey is a tactic used to slow and/or stop an opposing player involving body contact. Current studies have identified body checking as the most common cause of sports-related concussion in ice hockey across all divisions and levels. ${ }^{2,3}$ In response, many of the major hockey governing bodies have implemented rules making body checking to the head, face, and/or neck an illegal maneuver in certain young age groups. Beginning in 2011, Hockey Canada implemented Rule 6.5 summarized as the "zero tolerance for head contact" rule in Pee Wee (11-12 y old) leagues. ${ }^{4}$ The rule as it reads from the official referee's casebook ${ }^{5}$ states that, "any player who whether accidentally or intentionally contacts another player in the head, face, or neck with their stick or any part of their body or equipment may receive a penalty." Such a rule makes age 13 the first age in which individuals can engage in body checking in Canada. Despite these changes, effectiveness of their implementation on the incidence of concussion in male youth ice hockey players remains unclear.

\section{Focused Clinical Question}

What is the effect of body checking policy changes on concussion incidence in Canadian male youth ice hockey players?

\section{Summary of Search, "Best Evidence" Appraised, and Key Findings}

- The literature was searched for studies of level 3 or higher evidence that investigated the influence of body checking policy changes on concussion incidence in male youth ice hockey athletes.

- The literature search identified 5 possible studies related to the clinical question; 2 retrospective studies ${ }^{4,6}$ and 1 prospective study ${ }^{7}$ met the inclusion criteria and were included.

- Of the included published articles, 2 studies ${ }^{6,7}$ reported that the implementation of a body checking policy change showed a decrease in concussion incidence among male Pee Wee ice hockey players.

- One included article ${ }^{4}$ noted that when compared with previous seasons, following the implementation of the "zero tolerance for head contact" rule, there was an increased incidence of sports-related concussion.

\section{Clinical Bottom Line}

Ingram, Kay, Vander Vegt, and Register-Mihalik are with the Department of Exercise and Sport Science, The University of North Carolina at Chapel Hill, Chapel Hill, NC. Kay (mkay@email.unc.edu) is corresponding author. between changing body checking policy change and decreased
Currently, there is available evidence to support a direct link 
concussion incidence. ${ }^{3,6,7}$ However, additional research is needed to understand the broad and long-term implication of body checking policy change. In addition, further data are needed to differentiate between increased concussion incidence resulting from concussion education efforts that may improve disclosure and increased concussion incidence as a direct result of policy changes.

\section{Strength of Recommendation}

Grade B evidence exists that policy changes concerning body checking near the head, face, or neck decrease concussion incidence.

\section{Search Strategy}

\section{Terms Used to Guide Search Strategy}

- Patient/Client group: male, youth or adolescent, ice hockey players or athletes

- Intervention (or Assessment): body checking policy or rule change

- Comparison: pre versus post body checking policy change

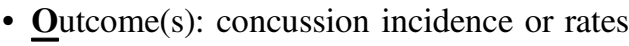

\section{Sources of Evidence Searched}

- PubMed

- SPORTDiscus

- MEDLINE

- Additional resources obtained via review of reference lists and hand search

\section{Inclusion and Exclusion Criteria}

\section{Inclusion Criteria}

- Level 3 evidence or higher

- Studies that investigated concussion incidence among youth ice hockey players

- Studies that investigated body checking rule changes and concussion incidence among youth ice hockey players

- Limited to English language

- Limited to the past 10 years (2008-2017)

\section{Exclusion Criteria}

- Studies that included individuals who were not eligible to play in youth or minor league hockey leagues

- Studies that included participants who played in youth or minor league hockey leagues operating outside of Hockey Canada's jurisdiction

\section{Results of Search}

Three relevant published studies ${ }^{4,6,7}$ were located and categorized as shown in Table 1 (based on Levels of Evidence, Centre for Evidence-Based Medicine). ${ }^{8}$
Table 1 Summary of Best Evidence

\begin{tabular}{llcl}
\hline $\begin{array}{l}\text { Level of } \\
\text { evidence }\end{array}$ & Study design & $\begin{array}{l}\text { Number } \\
\text { located }\end{array}$ & Reference \\
\hline 3 & $\begin{array}{l}\text { Retrospective } \\
\text { cohort study }\end{array}$ & 2 & $\begin{array}{l}\text { Black et al }^{6} \\
\text { Krolikowski et al }^{4} \\
\text { Black et al }^{7}\end{array}$ \\
\hline & $\begin{array}{l}\text { Prospective } \\
\text { cohort study }\end{array}$ & 1 & \\
\hline
\end{tabular}

\section{Best Evidence}

These studies included were identified as the best evidence and selected for inclusion in this critically appraised topic (CAT). Included articles were considered level 3 evidence or higher and investigated the effect of policy changes on concussion incidence in male youth ice hockey (Table 2).

\section{Implications for Practice, Education, and Future Research}

The 3 included studies ${ }^{4,6,7}$ in this CAT examined the relationship between body checking policy changes in Canadian male youth ice hockey and incidence of sports-related concussion. The studies ${ }^{4,6,7}$ categorized participants into 2 groups associated with the rules of their respective leagues at the time of data collection. Black et al ${ }^{6,7}$ conducted both a prospective and retrospective study that assessed concussion incidence before and after the implementation of a rule disallowing body checking. Both studies suggested that the removal of body checking from youth hockey at the Pee Wee age level in Canada can be associated with a decreased risk of concussion and concussion incidence during a playing season. Although Krolikowski et $\mathrm{al}^{4}$ also assessed concussion incidence as a result of body checking, the study encompassed 4 seasons from 2006-2007 to 2011-2012. The time frame of the study also encompasses the beginning of a push for increased awareness about the signs, symptoms, and long-term consequences surrounding concussions. During this time, a multitude of educational materials including the ThinkFirst Smart Hockey safety video were being distributed for consumption by youth athletes. The increased concussion incidence suggested by this study may likely be a result of increased awareness and likelihood to report concussion-like symptoms known as concussion disclosure.

The findings of this CAT suggest that limiting the exposure players have with direct contact to their head, face, and neck through policy changes can reduce the incidence of sports-related concussion in youth ice hockey players, at least at the Pee Wee level (ages 11-13) in Canada. However, Krolikowski et $\mathrm{al}^{4}$ found an increase in the risk of more severe concussions, defined as 10 or more days of playing time lost, in the season immediately following the body checking policy change, which can also be attributed to increased awareness and conservative return-to-play guidelines as outlined by the Zurich consensus statement on concussion in sport. ${ }^{10}$ As stated in the National Athletic Trainer's Association's best practice guidelines, ${ }^{11}$ athletic trainers should work to educate coaches and parents about concussions including potential mechanisms of injury. The findings of this CAT can aid athletic trainers' communication with coaches and parents about the potential injury that may be caused from body checking and the modification based on age to prevent sports-related concussions as well as other injuries. 
Table 2 Characteristics of Included Studies

\begin{tabular}{|c|c|c|c|}
\hline & Black et $\mathrm{al}^{6}$ & Krolikowski et al ${ }^{4}$ & Black et al $^{7}$ \\
\hline Study design & Retrospective cohort study & Retrospective cohort study & Prospective cohort study \\
\hline Participants & $\begin{array}{l}\text { Baseline information, injury, and } \\
\text { exposure data were collected for } \\
883 \text { youth ice hockey players. } \\
\text { Inclusion criteria: male Pee Wee } \\
\text { hockey players associated with } \\
\text { Hockey Canada. } \\
\text { Participants completed a Preseason } \\
\text { Baseline Questionnaire and Sport } \\
\text { Concussion Assessment Tool } \\
\text { administered by trained research } \\
\text { assistants. } \\
\text { Exclusion criteria: Participants } \\
\text { were excluded if they were a part } \\
\text { of a team that did not agree to track }\end{array}$ & $\begin{array}{l}\text { Demographic, equipment, and } \\
\text { medical history were collected for } \\
2099 \text { male youth ice hockey players } \\
\text { upon entry to the study. Injury and } \\
\text { exposure data were collected pro- } \\
\text { spectively through each season from } \\
\text { each participant. } \\
\text { Inclusion Criteria: Pee Wee and } \\
\text { Bantam hockey players registered } \\
\text { in Hockey Calgary and Hockey } \\
\text { Edmonton. } \\
\text { Data from each participant were } \\
\text { collected from a previously validated } \\
\text { injury surveillance system. }\end{array}$ & $\begin{array}{l}\text { Baseline, demographic, and risk } \\
\text { factor information were collected } \\
\text { for } 1331 \text { male youth hockey players } \\
\text { during the 2011-2012 season. } \\
\text { Inclusion criteria: male Pee Wee } \\
\text { hockey players during 2011-2012 } \\
\text { season. } \\
\text { Participants completed a baseline } \\
\text { questionnaire including questions } \\
\text { pertaining to demographics and risk } \\
\text { factors. } \\
\text { Exclusion criteria: Participants were } \\
\text { excluded if they were participating } \\
\text { in "girls-only" leagues. }\end{array}$ \\
\hline
\end{tabular}
their weekly participation and report injuries. Participants were also excluded if they were concussed at the beginning of the study.

Intervention

investigated

Outcome measure(s)

Main findings

Level of evidence
Injury data from 2 cohorts were collected from Pee Wee hockey teams associated with Hockey Canada. The first cohort included injury data from Pee Wee teams during the 2011-2012 season when body checking was permitted $(\mathrm{n}=883)$. The second cohort included injury data from Pee Wee teams during the 2013-2014 season $(\mathrm{n}=618)$ when Hockey Canada's policy changed to "zero tolerance for head contact."

Number of injuries or concussions, time lost due to injury, mechanism of injury, and absolute risk reduction associated with removal of checking.

The total number of injuries and concussions following the implementation of a rule change in the 2013-2014 season (48 game injuries/ 25 concussions) decreased from the 2011-2012 season (163 game injuries/104 concussions).

The policy change disallowing body checking is associated with a decreased injury rate $(\operatorname{IRR}=0.50)$, specifically concussions ( $I R R=0.36$ ) when compared with the previous total injury rate $(I R R=1.70)$ and the previous concussion rate $(\mathrm{IRR}=2.48)$.

When comparing the 2011-2012 and 2013-2014 mechanisms of injury, there was a significant difference between the rate of injuries due to body checking (IRR $=0.16$ and 0.21 , respectively).
Exclusion criteria: Participants were excluded if they participated in a "girls only" Pee Wee league or sustained a previous injury or chronic illness that prevented full participation at the beginning of the season.

Injury data from 4 prospective cohorts (study years from 2006-2007 to 2011-2012) were collected $(\mathrm{n}=2099)$.

Number of concussions, incidence rate ratios, and game-related mechanisms of concussion.

The number of concussions sustained by youth ice hockey players increased from 99 overall to 170 , following the rule change.

Following the implementation of Rule 6.5, youth hockey players in both Pee Wee (adjusted IRR = 1.85) and Bantam (adjusted IRR $=2.48$ ) had a significantly higher risk of game-related concussions when compared with youth ice hockey players before the enforcement of the rule.

Concussion incidence due to body checking increased following the rule change for both Pee Wee and Bantam leagues $(\mathrm{IRR}=1.77$ and 2.36, respectively).
Injury data were collected from 2 cohorts of Pee Wee hockey players. The first cohort included injury data from Pee Wee teams where body checking was disallowed during the 2011-2012 season. The second cohort included injury data from Pee Wee teams where body checking was allowed during the 2011-2012 season.

Incidence rate ratio and concussion incidence rate.

In leagues that allowed body checking, there was a significantly greater overall rate of injury $(I R R=2.97)$ and concussion (IRR $=2.83)$.

In leagues where body checking was permitted, the primary mechanism of injury was body checking, whereas in leagues where body checking was disallowed, the primary mechanism of injury was unintentional contact. 
Table 2 (continued)

\begin{tabular}{|c|c|c|c|}
\hline & Black et $\mathrm{al}^{6}$ & Krolikowski et al ${ }^{4}$ & Black et $\mathrm{al}^{7}$ \\
\hline $\begin{array}{l}\text { Validity score } \\
\text { (if applicable) }\end{array}$ & N/A & N/A & N/A \\
\hline Conclusion & $\begin{array}{l}\text { There was a significant decrease in } \\
\text { injury and concussion risk associated } \\
\text { with the removal of body checking } \\
\text { from Pee Wee hockey leagues. } \\
\text { There was also a significant decrease } \\
\text { in the incidence of injury as a result } \\
\text { of body checking. }\end{array}$ & $\begin{array}{l}\text { The risk of sport-related concussion } \\
\text { and more severe concussions } \\
\text { increased in Pee Wee hockey leagues } \\
\text { following the Hockey Canada's } \\
\text { "zero tolerance for head contact" } \\
\text { rule. }\end{array}$ & $\begin{array}{l}\text { In Pee Wee ice hockey leagues that } \\
\text { do not permit body checking, there is } \\
\text { a decreased rate of injury, including } \\
\text { concussions. }\end{array}$ \\
\hline
\end{tabular}

Abbrevations: IRR indicates incidence rate ratio; N/A, not applicable.

Future research investigations should be completed to differentiate between policy changes and education efforts as factors that influence changes in risk of concussions and concussion incidence rates in youth ice hockey players in all geographic areas. Research in this area would help athletic trainers identify modifiable factors affecting concussion incidence allowing clinicians to take a more systematic approach in the prevention of sports-related concussions. Future research should also be conducted to evaluate the effect of delaying body checking on the incidence of concussions in older players.

This CAT should be reviewed in 2 years to determine whether additional best research evidence has been published that could aid in answering the focused clinical question or may change the clinical bottom line for this specific clinical question.

\section{References}

1. Hockey Canada. Annual Report 2016-2017 (pp. 15-16). https://cdn. hockeycanada.ca/hockey-canada/Corporate/About/Downloads/ 2016-17-annual-report-e.pdf. Accessed 10 January, 2017

2. Agel J, Dompier TP, Dick R, Marshall SW. Descriptive epidemiology of collegiate men's ice hockey injuries: National Collegiate Athletic Association injury surveillance system, 1988-1989 through 20032004. J Athl Train. 2007;42(2):241-248. PubMed ID: 17710172 doi:10.1016/S0276-1092(08)79204-6

3. Emery CA, Goulet C, Hagel BE, et al. Risk of injury associated with body checking among youth ice hockey players. JAMA. 2014; 303(22):2265-2272.

4. Krolikowski MP, Black AM, Palacios-Derflingher L, Blake TA, Schneider KJ, Emery CA. The effect of the "zero tolerance for head contact" rule change on the risk of concussions in youth ice hockey players. Am J Sports Med. 2017;45(2):468-473. PubMed ID: 27789471 doi:10.1177/0363546516669701

5. Hockey Canada. Referee's Case Book/Rule Combination 2016-2018. 2016. https://az184419.vo.msecnd.net/hockey-canada/HockeyPrograms/Officiating/Downloads/rulebook_casebook_e.pdf. Accessed 10 January, 2017

6. Black AM, Hagel BE, Palacios-Derflingher L, Schneider KJ, Emery CA. The risk of injury associated with body checking among Pee Wee ice hockey players: an evaluation of Hockey Canada's national body checking policy change. Br J Sports Med. 2017; 51(24):1767-1772. PubMed ID: 28279963 doi:10.1136/bjsports2016-097392

7. Black AM, Macpherson AK, Hagel BE, et al. Policy change eliminating body checking in non-elite ice hockey leads to a threefold reduction in injury and concussion risk in 11- and 12-year-old players. Br J Sports Med. 2016;50(1):55-61. PubMed ID: 26702018 doi:10. 1136/bjsports-2015-095103

8. https://www.cebm.net/wp-content/uploads/2014/06/CEBM-Levelsof-Evidence-2.1.pdf

9. Emery CA, Meeuwisse WH. Injury rates, risk factors, and mechanisms of injury in minor hockey. Am J Sports Med. 2006;34(12):1960 1969. PubMed ID: 16861577 doi:10.1177/0363546506290061

10. McCrory P, Meeuwisse W, Dvorak J, et al. Consensus statement on concussion in sport- the 5th international conference on concussion in sport held in Berlin, October 2016. Br J Sports Med. 2017;51(11):838847. PubMed ID: 28446457 doi:10.1136/bjsports-2017-097699

11. Broglio SP, Cantu RC, Gioia GA, et al. National athletic trainers' association position statement: management of sport concussion. J Athl Train. 2014;49(2):245-265. PubMed ID: 24601910 doi:10. 4085/1062-6050-49.1.07 